\title{
ENGEVISTA
}

Página da revista: http://www.uff.br/engevista/seer/

\section{Assessment of dryer performance under intermittent drying of grains in fixed bed}

\author{
Rafael Oliveira Defendi ${ }^{1}$ \\ Paulo Roberto Paraíso ${ }^{2}$ \\ Luiz Mario de Matos Jorge 3
}

Resumo: A secagem intermitente é um tipo de operação que visa melhorar o desempenho do processo de secagem por meio de modulações das condições do ar como sua temperatura e velocidade na entrada do secador, contrariamente a operação convencional, na qual as condições do ar são mantidas em valores constantes. Este tipo alternativo de operação foca em determinar as melhores condições de modulação do ar a fim de minimizar o consumo energético, maximizar o desempenho do secador ou melhorar a qualidade do material. Neste contexto, este trabalho objetiva simular o processo de secagem de alguns grãos em leito fixo e avaliar se é possível aumentar com a operação intermitente o desempenho do secador em termos de taxa de secagem em comparação com resultados obtidos em operação convencional. Ambas as operações convencionais e intermitentes foram simuladas em condições de mesmo consumo energético relacionado à energia fornecida pelo ar na entrada do secador. Resultados apontaram que as taxas de secagem foram maiores em operação intermitente com modulação da temperatura do ar em comparação com os resultados obtidos em operação convencional com a temperatura do ar mantida em valores constantes. Além disso, observou-se em alguns casos que os valores de amplitude e período inerentes a estas modulações podem interferir nas taxas de secagem.

Palavras-chave: Secagem intermitente, arroz, feijão, milho, soja.

\footnotetext{
${ }^{1}$ UEM - Universidade Estadual de Maringá

${ }^{2}$ UEM - Universidade Estadual de Maringá

${ }^{3}$ UEM - Universidade Estadual de Maringá
} 
ISSN: $1415-7314$

ISSN online: 2317-6717

Abstract: Intermittent drying is an operation that aims to improve drying process performance with modulations of inlet air conditions such as its temperature and velocity, contrary to the conventional operation, in which air conditions are constant. This alternative operation aims to determine the best modulation pattern of air conditions to minimize energy consumption, maximize dryer performance or improve material quality. In this context, the objectives of this work are to simulate the drying process of some grains in fixed bed and assess if it is possible to enhance the dryer performance in terms of drying rates under intermittent operation in comparison with results obtained with conventional operation. Both intermittent and conventional operations were simulated with the same energy consumption related to the energy supplied by the air at the dryer entrance. Results revealed that the drying rates were higher under intermittence of inlet air temperature in comparison with results obtained under conventional operation with constant inlet air temperature. In addition, it was observed in some simulations that the amplitude and period values related to modulations can impact on drying rates.

Keywords: Intermittent drying, rice, beans, corn, soybean. 


\section{Introduction}

Brazil is one of the leading countries in terms of exportation and production of grains. One of the most important processes during the production of these grains is the drying process, which can enable materials to achieve safe levels of moisture content to avoid product deterioration during storage. However, costs involved in grain drying process can be significantly high. According to Silva et al. (2000), drying process of agricultural products can demand $60 \%$ or even more of the total energy consumed during these products production.

An alternative operation to reduce costs is the intermittent drying, which supplies the drying system with time-varying inlet air conditions, contrary to the conventional operation, in which air conditions are constant. One of the principal aims of the intermittent operation is to establish the best modulation pattern of air conditions to minimize energy consumption, maximize the performance of the dryer or improve material quality.

According to Chua et al. (2003), intermittent drying is beneficial for drying systems controlled by diffusion effects inside the solid. It was observed that diffusion effects controlled the drying rates of a variety of agricultural products (AKPINAR et al., 2003; ARABHOSSEINI et al., 2009; BENALI, 2012; CHINENYE et al., 2010; CIL e TOPUZ, 2010; DEFENDI et al., 2015a; DEMIR et al., 2007; MEISAMI-ASL et al., 2010; OLIVEIRA e ROCHA, 2007; SILVA et al., 2014; VEGA-GÁLVEZ et al., 2012). For these products, there might be a waste of energy if the drying operation is continuously conducted at high temperature. In some cases, it is interesting to alternatively work at high temperature and then wait the diffusive effects occur at tempering periods of low temperature.

Intermittent drying can also improve the drying system in terms of material quality, especially for heat-sensitive materials (CHUA et al.; 2003). If the drying process is carried out continuously at high temperature, there might be a significant loss of material quality. Some authors observed that time-varying conditions of the inlet air can preserve better material quality in comparison with results obtained with the continuous operation (BON e KUDRA, 2007; CHIN e LAW, 2010; CHONG e LAW, 2011; FARKAS et al., 1997; KOWALSKI e PAWOWSKI, 2010 a,b; ONG et al., 2012; PAN et al., 1998; PAN et al., 1999; THOMKAPANICH et al., 2007; KOWALSKI e SZADZINSKA, 2014).

Other authors observed that the intermittent drying cal also reduce the energy consumption in comparison with the conventional operation (CHIN e LAW, 2010; HOLOWATY et al., 2012; JUMAH et al., 2007; LIMA e NEBRA, 2001; PAN et al., 1998; THOMKAPANICH et al., 2007; ZHANG e LITCHFIELD, 1991).

It was also possible to improve the dryer performance and reduce the net drying time under intermittent operation in comparison with results obtained with the traditional operation (CHIN e LAW, 2010; CHONG e LAW, 2011; FARKAS et al., 1997; HERRITSCH et al., 2010; KOWALSKI 
e SZADZINSKA, 2014 ONG et al., 2012; PAN et al., 1998; PAN et al., 1999; THOMKAPANICH et al., 2007; ZHANG e LITCHFIELD, 1991). Defendi et al. (2015b) observed an increase of the drying rates by applying air temperature modulations at the dryer entrance, when both intermittent and conventional operations demanded the same energy consumption and drying time.

In this context, this work aims to simulate the drying process of some grains (rice, beans, corn and soybean) under intermittent and conventional operations based on kinetics equations from the literature. Both intermittent and continuous operations were simulated with the same drying time and energy consumption. It was assessed if it was possible to improve the dryer performance in terms of drying rates by applying modulations in the inlet air temperature.

\section{Methods}

\subsection{Model for Corn Drying}

Corn drying system was simulated based on a classical thin layer model in which accumulation of water inside the grain is equal to the quantity of water evaporated within time:

$$
\frac{d M}{d t}=-\frac{K s \cdot A s}{m_{s}}\left(M-M_{e}\right)
$$

$K s$ is the global mass transfer coefficient, $A s$ is the grain superficial area, $M$ is the grain moisture content in dry-weight basis, $M e$ is the equilibrium moisture content, $m_{s}$ is the bone-dry solid mass and $t$ is the time. As the grain surface is difficult to be estimated, the following parameter was assumed:

$$
K=\frac{K s A s}{m_{s}}
$$

$K$ is a reference mass transfer coefficient. The thin layer model results expressed by Equation 1 resulted in:

$$
\frac{d M}{d t}=-K\left(M-M_{e}\right)
$$

This equation is analogous to the Newton's Law of Cooling and this model had previously proposed by Lewis (1921). According to Henderson e Perry (1955), this equation describes the falling rate period when the drying rates decrease over time. Equation 3 was used to simulate the intermittent and conventional operations and $K$ was estimated based on the equation adjusted by Mancini et al. (2002a) for drying of corn: 


$$
K_{S} a=K \rho_{S S}=(7.31-0.0177 T) M-(2.20-0.00618 T)
$$

$K_{s} a$ is the volumetric mass transfer coefficient whose unit is $\mathrm{kg} / \mathrm{m}^{3} \mathrm{~s}, \rho_{s s}$ is the corn bone-dry density and $T$ is the air temperature in Kelvin. Corn density was estimated based on the study carried out by Santos et al. (2012).

During intermittent drying simulations, the air temperature was modulated like a sine wave as illustrated in Figure 1. The equation used to calculate the air temperature modulation was the following:

$$
T_{I}=A m p \cdot \operatorname{sen}(\text { fr.t. } 2 \pi)+T_{c}
$$

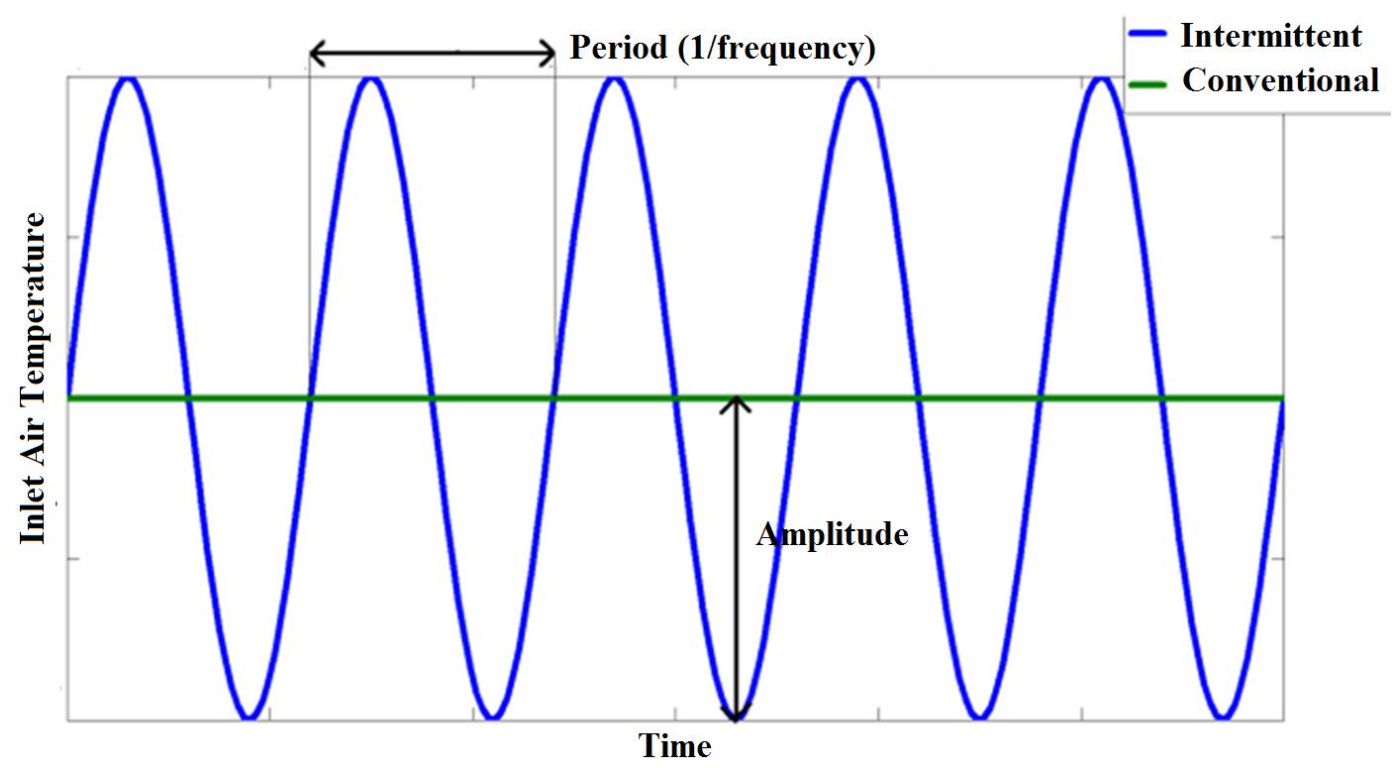

Figure 1. Inlet Air Temperature Modulation

$T_{I}$ is the intermittent temperature, $A m p$ is the amplitude, $f r$ is the frequency, and $T_{C}$ is the air temperature for conventional operation. Simulations with intermittent operation were conducted with period values from 6 to $60 \mathrm{~min}$ and amplitudes values form 7 to $20^{\circ} \mathrm{C}$. Initial moisture content of corn was assumed 0.18 in dry-weight basis and initial air moisture content as assumed zero. In this condition, the equilibrium moisture content was also assumed zero.

For each intermittent simulation, it was simulated a conventional operation with the same drying time (2 hours) and energy consumption of the intermittent operation. Energy consumption was estimated based on the following equation: 


$$
E=G \cdot \int_{0}^{t} c p_{a i r} \cdot T \cdot d t
$$

$E$ is the consumed energy, $G$ is the mass flow rate and $c p_{a i r}$ is the air specific heat. To guarantee the same energy consumption for both operations, the conventional operation was conducted with an average air temperature value of its respective intermittent operation. Average air temperature was calculated with Equation 7 . With this average temperature, intermittent and conventional operations had the same energy consumption at the end of drying process based on Equation 6.

$$
\bar{T}=\frac{\int T \cdot d t}{\int d t}
$$

\subsection{Model for Soybean Drying}

Soybean drying simulations were conducted based on the classical thin layer model previously described and represented by Equation 3. $K$ was estimated with equation adjusted by Defendi et al. (2014):

$$
K=\frac{\alpha_{1} \cdot M^{2}+\alpha_{2} \cdot M+\alpha_{3}}{M_{0}-M+\alpha_{4}}
$$

$\mathrm{M}_{0}$ is the initial soybean moisture content and $\alpha_{\mathrm{i}}$ are the model's parameters:

$$
\begin{aligned}
& \alpha_{1}=3.818 \times 10^{-4}-1.258 \times 10^{-5} \mathrm{~T} \\
& \alpha_{2}=9.274 \times 10^{-7}+7.282 \times 10^{-6} \mathrm{~T} \\
& \alpha_{3}=-1.065 \times 10^{-5}-4.840 \times 10^{-7} \mathrm{~T} \\
& \alpha_{4}=3.903 \times 10^{-2}-5.001 \times 10^{-4} \mathrm{~T}
\end{aligned}
$$

Air temperature was also modulated based on Equation 5 and for each intermittent operation simulation it was simulated a conventional operation with the same energy consumption. Amplitude 
values of air temperature modulation were assumed between 5 and $15^{\circ} \mathrm{C}$ and period values were assumed between 6 and 60 minutes. Drying time was 2 hours and initial moisture content of soybean was 0.14 . Analogously to the previous case, air moisture content and grain equilibrium moisture content were considered zero.

\subsection{Model for Rice Drying}

The thin layer model used to simulate drying rice was proposed by Thompson et al. (1968):

$$
t=A \ln (M R)+B(\ln (M R))^{2}
$$

$A$ and $B$ are the model's parameters and $M R$ is moisture content ratio calculated with the following equation:

$$
M R=\frac{M-M_{e}}{M_{0}-M_{e}}
$$

Values of $A$ and $B$ were adjusted by Mata (1992) for thin layer drying of rice:

$$
\begin{gathered}
A=-2445.06+82.79 T-1.023 T^{2}+0.004267 T^{3} \\
B=-449.68+14.52 T-0.182 T^{2}+0.000756 T^{3}
\end{gathered}
$$

$T$ unit is ${ }^{\circ} \mathrm{C}$ and time unit is seconds. Model represented by Equation 13 was solved with 200 divisions in time, which led to a system with 200 algebraic equations to be solved. For intermittent operation, $A$ and $B$ values varies with the variation of air temperature. For each discretized point of the model solution, the initial moisture content was assumed as the moisture content of the previous discretized point and the value of time for each discretized point was assumed as the interval between two discretized points. This methodology consider each discretized point as a starting drying point based on moisture content data of the previous discretized point.

Similarly to the previous cases, the air temperature for intermittent operation was modulated based on Equation 5 and both conventional and intermittent operations were simulated with the same energy consumption and drying time ( 2 hours). Initial rice moisture content was assumed 0.18 in dry-weight basis and air moisture content was assumed zero. Equilibrium moisture content of rice was also considered zero. Amplitude and period of air modulation were simulated respectively with values between 10 and $30{ }^{\circ} \mathrm{C}$ and values between 6 and 60 minutes.

\subsection{Model for Beans Drying}


Drying of beans was simulated in deep bed layer with the heterogeneous drying model of grains. This model is composed of a system with 4 differential equations that describe the moisture content and temperature profiles along the dryer and over time. Simulations were carried out based on a isolated cylindrical dryer with $30 \mathrm{~cm}$ of length and $3 \mathrm{~cm}$ of radius. Model's assumptions were similar as the considerations assumed by other authors (CALÇADA, 1994; COUTINHO et al., 2009; DEFENDI et al., 2015b) and the equation system of the heterogeneous model resulted in:

$$
\begin{gathered}
\frac{\partial Y g}{\partial z}=\frac{K_{s} a\left(Y s-Y s_{e}\right)}{G g} \\
G g \cdot\left(c p_{a i r}+Y g c p_{v}\right) \frac{\partial T g}{\partial z}=-h a(T g-T s) \\
\frac{\partial Y s}{\partial t}=-\frac{K_{s} a\left(Y s-Y s_{e}\right)}{(1-\varepsilon) \rho_{S S}} \\
(1-\varepsilon) \rho_{s s}\left(c p_{s}+Y Y_{s} \cdot c_{l}\right) \frac{\partial T s}{\partial t}=h a(T g-T s)-K_{s} a\left(Y s-Y s_{e}\right)\left(c p_{v}(T g-T s)+\lambda\right)
\end{gathered}
$$

$Y g$ is the air moisture content in dry-weight basis, $z$ is the axial position inside the dryer, $Y s$ is the grains moisture content in dry-weight basis, $G g$ is the gas mass flux, $c p_{v}$ is the vapor specific heat, $T g$ is the gas temperature, $h a$ is the global heat transfer coefficient between the solid and the gas, $T s$ is the solid temperature, $\varepsilon$ is the bed porosity, $c p_{s}$ is the solid specific heat, $c p_{l}$ is the liquid specific heat and $\lambda$ is the latent heat of vaporization.

Bed porosity was estimated based on data obtained by Resende et al. (2008). Specific heat of beans was assumed based on the study carried out by Mata et al. (1999). Global heat transfer coefficient was calculated with equation adjusted by Boyce (1965):

$$
h a=4286.5 \cdot\left[\frac{G g \cdot T_{g}}{P}\right]^{0.6011}
$$


$G g$ unit is $\mathrm{kgm}^{-2} \mathrm{~min}^{-1}, T_{g}$ unit is Kelvin, $P$ unit is $\mathrm{Pa}$ and $h a$ unit is $\mathrm{kJ} \cdot \mathrm{m}^{-3} \mathrm{~min}^{-1} \mathrm{C}^{-1}$. Properties of gas, vapor and liquid were estimated based on data presented by Perry and Green (1998). Mass transfer coefficient of beans was calculated based on equation adjusted by Mancini et al. (2002b):

$$
K_{s} a=\beta_{1} Y s-\beta_{2}
$$

$$
\beta_{1}=1.55-0.00226 \mathrm{Tg}
$$

$$
\beta_{2}=1.01-0.00277 \mathrm{Tg}
$$

Unit of $T g$ is Kelvin for Equations 23 and 24. Both intermittent and conventional operations were simulated with the same energy consumption related to Equation 6. Air temperature was modulated based on Equation 5 with amplitude values between 7 and $20{ }^{\circ} \mathrm{C}$ and period values between 6 and 60 minutes. Initial moisture content of beans was assumed as 0.20 in dry-weight basis and inlet air moisture content was assumed zero. Air flow rate was considered $100 \mathrm{~L} / \mathrm{min}$ and equilibrium moisture content of beans was assumed zero.

\section{Results and discussion}

\subsection{Corn Drying}

For corn drying simulations, it was observed that intermittent operation with inlet air temperature modulation can be more beneficial in terms of drying rates in comparison with results simulated under continuous operation. It was verified that the intermittent operation increased drying rates leading corn moisture content to lower levels in comparison with continuous operation results, when both intermittent and conventional operations were conducted with the same energy consumption.

Figure 2 presents corn moisture content profile for different amplitudes related to inlet air temperature modulation. In this graphic, it is possible to infer that high levels of amplitude benefit intermittent drying as the final moisture content decreased by enhancing amplitude. In addition, it was verified that for low amplitudes $\left(7^{\circ} \mathrm{C}\right)$ of inlet air temperature modulation, the conventional operation had a better performance leading to lower level of final moisture content in comparison with intermittent operation. 
ISSN: $1415-7314$

ISSN online: $2317-6717$

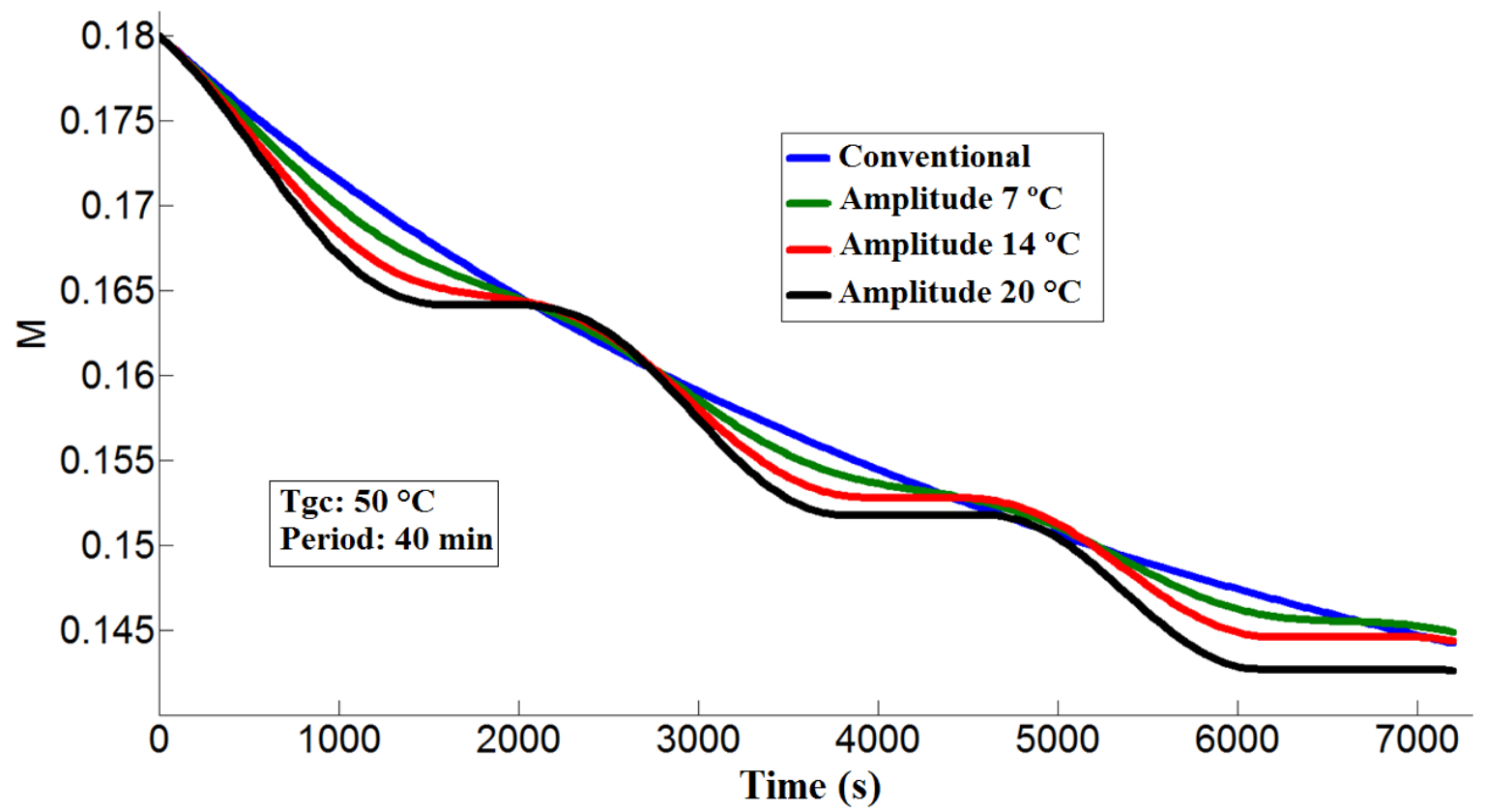

Figure 2. Corn Moisture Content for Different Amplitudes of Temperature Modulation

It was also observed that drying rates for intermittent operation enhanced more significantly over time in comparison with results from simulations of conventional operation as it can be observed in Figure 3, which depicts a drying simulation of 4 hours. It is interesting to compared conventional and intermittent operation at the end of each air temperature modulation (vertical lines of Figure 3), because energy consumption are similar for both operations at these moments.

At the first drying minutes, conventional operation presents better performance, as moisture content is lower. However, there is a gradual improvement of intermittent drying performance over time as moisture content keeps getting lower at the end of each modulation in comparison with conventional operation results. At the end of the 4 hours of drying, moisture content for intermittent drying is significantly lower than moisture content of conventional operation.

Periods related to inlet air temperature modulation also impacted on moisture content of corn as it can be verified in Figure 4. For low value of period (6 min), moisture content curve maintained at lower levels during all drying time in comparison with moisture content curve of conventional operation. High value of period increases the time that corn is in contact with air at low temperature levels during the first moment of drying. This fact may explain the reason moisture content curve of high period values can be higher than moisture content curve of conventional operation. However, all intermittent operation had the same final moisture content regardless period value. It is interesting to highlight that at the end of the drying simulation, all intermittent curves and conventional curve had the same energy consumption.

\subsection{Soybean Drying}


Soybean drying kinetics under intermittent and conventional operation was similar to results obtained with corn drying. Drying rates were higher under intermittence as the final moisture content of soybean achieved lower levels in comparison with results obtained with conventional operation conducted with the same energy consumption. There was a tendency to increase drying rates by enhancing the amplitude value of inlet air temperature modulation as it can be observed in Figure 5, which is analogous to corn drying results. Period impact on drying rates was also similar as it can be observed in Figure 6 in which it is possible to observe that at the end of drying process all intermittent curves achieved the same moisture content regardless the value of period.

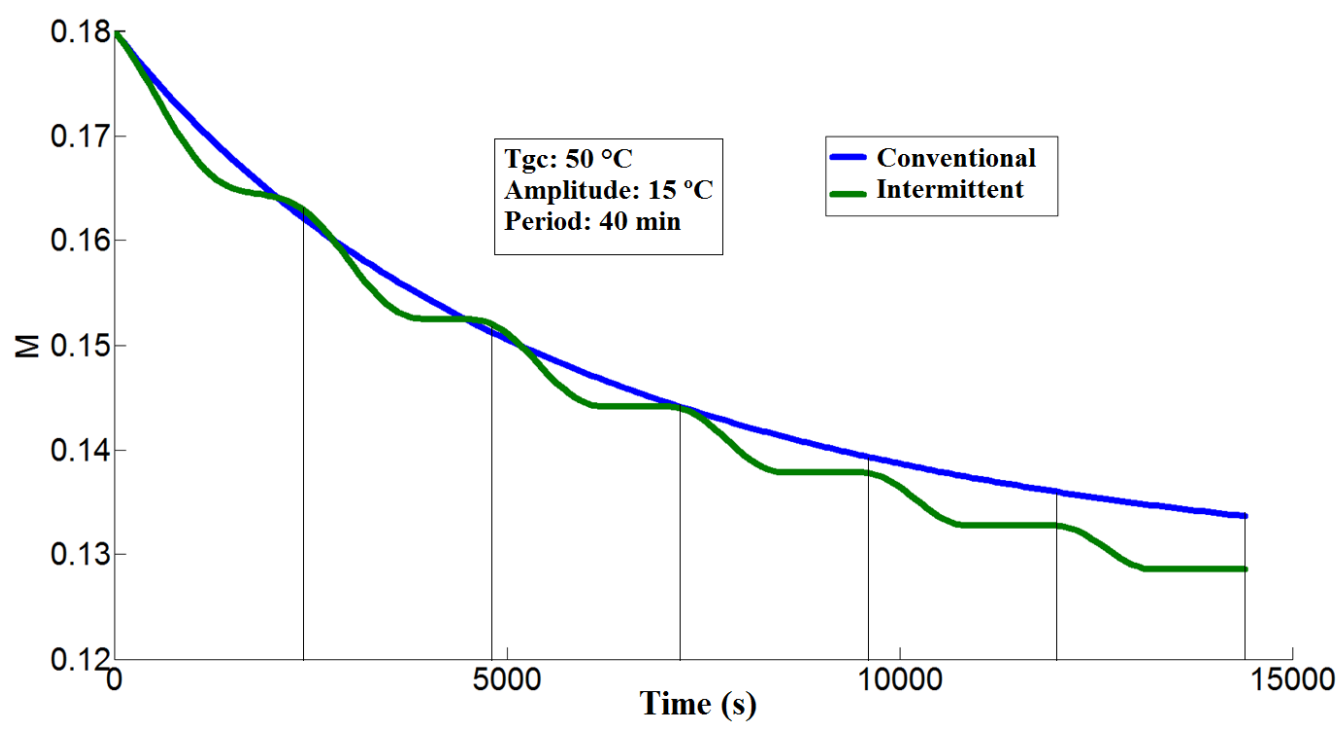

Figure 3. Corn Moisture Content under Conventional and Intermittent Operation

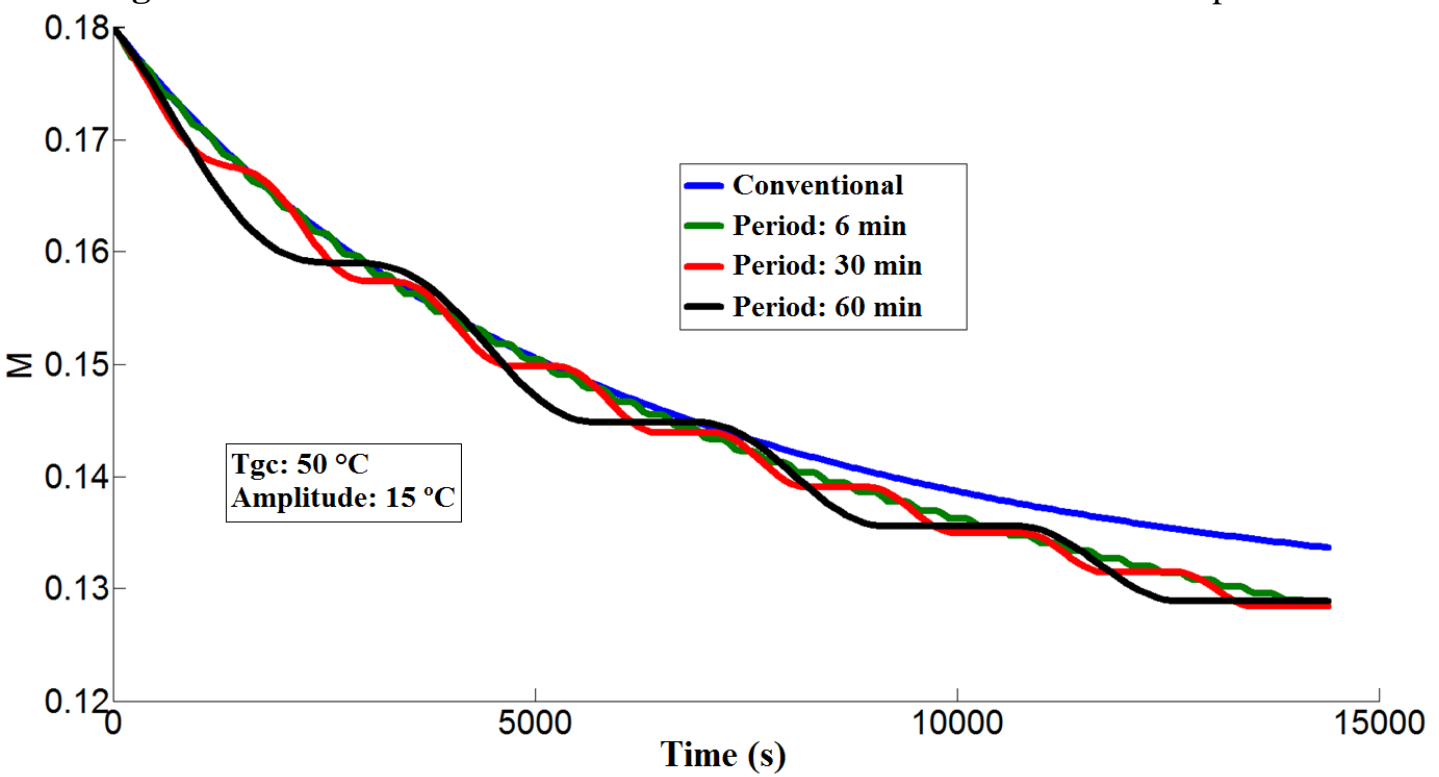

Figure 4. Corn Moisture Content for Different Periods of Temperature Modulation 
ISSN: $1415-7314$

ISSN online: $2317-6717$

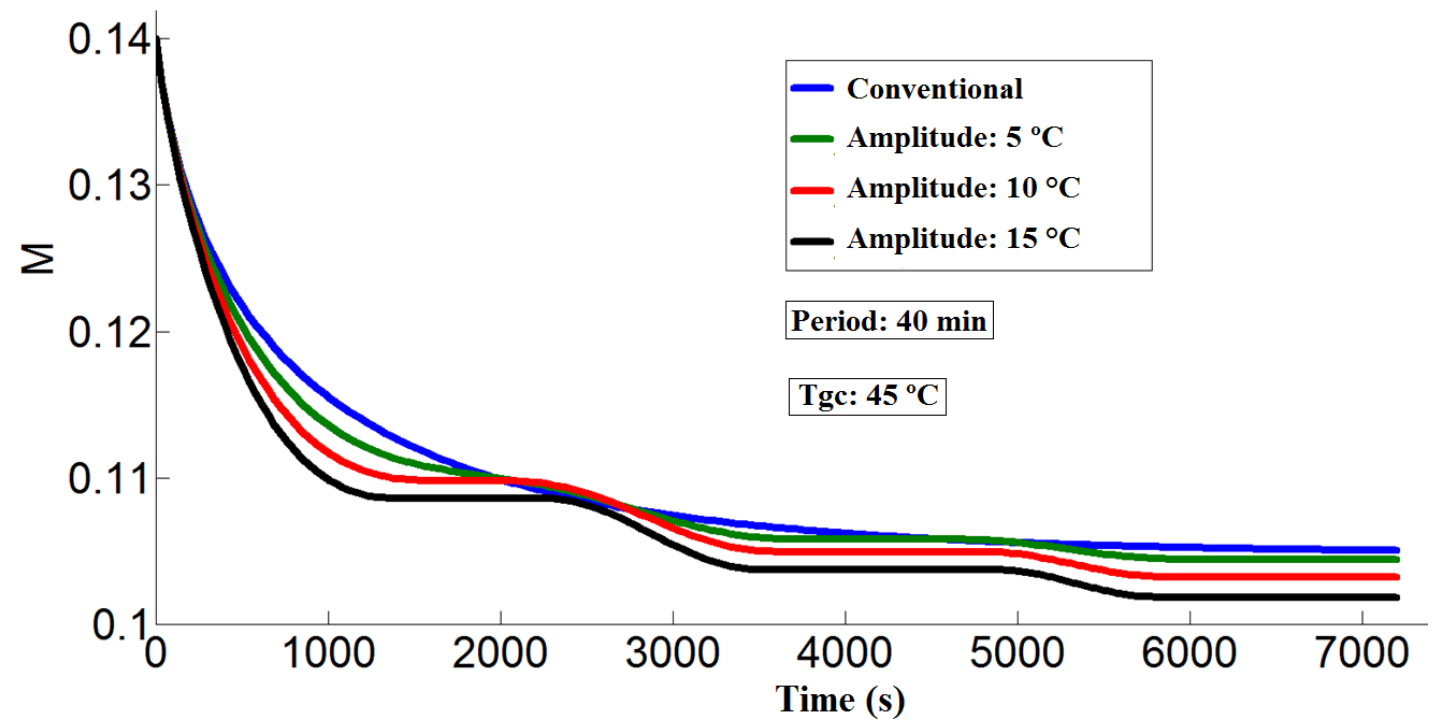

Figure 5. Soybean Moisture for Different Amplitudes of Temperature Modulation

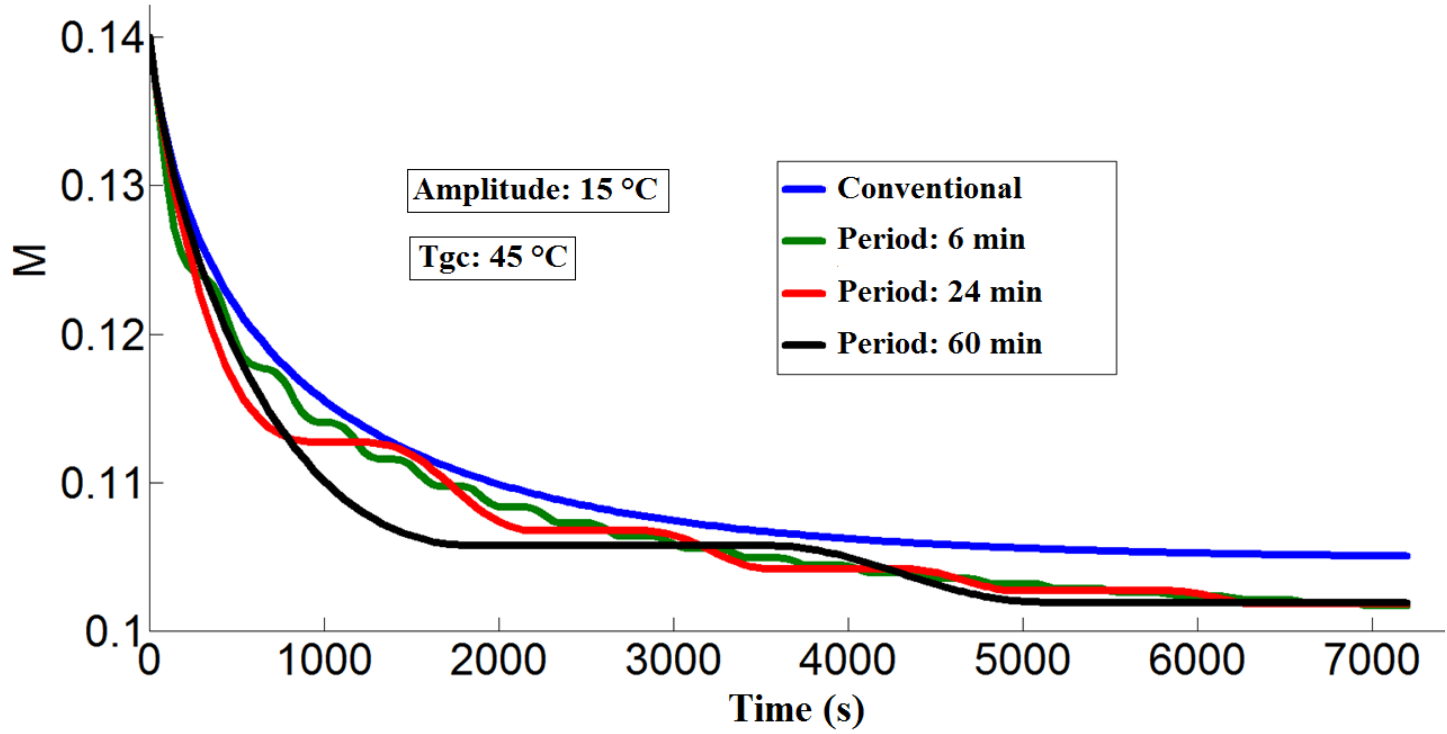

Figure 6. Soybean Moisture Content for Different Periods of Temperature Modulation

\subsection{Rice Drying}

For rice drying simulations, it was also observed that the modulation of inlet air temperature can improve dryer performance in comparison with results obtained with constant inlet air temperature in cases where both intermittent and conventional operations were simulated with the same energy consumption and drying time. Moisture content level of rice was lower under intermittence of air temperature, especially at high values of amplitude as it can be inferred from results presented in Figure 7.

Analogously to previous cases of corn and soybean drying, the lowest levels of rice moisture content was obtained with the highest value of amplitude $\left(30^{\circ} \mathrm{C}\right)$. High level of amplitude leads to a superior peak of inlet air temperature, but it also leads to minimum values of inlet air temperature. 
Drying rates enhances by increasing air temperature. Based on these results, drying rates at the highest temperature levels compensate drying rates at the lowest temperature levels in comparison with conventional operation results carried out with average inlet air temperature and in comparison with intermittent operations with lower amplitude related to inlet air temperature modulation. This compensation can also be explained based on mass transfer coefficient equations as they are not linear depend on air temperature.

Another interesting aspect of rice drying to be highlighted is that intermittence of inlet air temperature showed to be beneficial during the first minutes of drying. Contrary to corn drying, the difference between the convention and intermittent moisture content when energy consumption is the same (vertical lines of Figure 7) keeps getting lower and in some cases the conventional moisture content achieves lower levels in comparison with intermittent operation. These results showed that conventional operation can be more beneficial in terms of drying rates depending on drying time and amplitude of inlet air temperature.

The impact of period related to inlet air temperature modulation for rice drying can be observed in Figure 8. Similarly to previous corn and soybean drying simulations, all intermittent operations achieved the same final moisture content regardless period value. However, final moisture content of intermittent operation was lower in comparison with conventional operation results.

\subsection{Beans Drying}

Drying rates were also higher with high values of amplitude related to inlet air temperature modulation for beans drying as it can be verified in Figure 9 which shows average value of beans moisture content for different amplitudes. Intermittent drying achieved lower levels of moisture content in comparison with conventional operation carried out with the same energy consumption. However, for low values of amplitude $\left(7^{\circ} \mathrm{C}\right)$, intermittent operation presented a similar drying performance to conventional operation.

It was also observed that beans moisture content was different along the dryer position. Figure 10 depicts beans moisture content at the entrance and exit of dryer for both intermittent and conventional operations. From these results, it is possible to infer that either at entrance or exit of the dryer, moisture content of intermittent operation was lower than moisture content of conventional operation, namely intermittent operation presented superior drying rates.

Period value related to inlet air temperature modulation also impacted on drying rates as it can be observed in Figure 11. For low value of period ( $6 \mathrm{~min}$ ), intermittent operation presented similar moisture content curve to conventional operation, namely both intermittent and conventional operations had similar performance related to drying rates. However, for period values of 24 and 60 min, intermittent operation achieved lower levels of moisture content in comparison with conventional operation results. However, there are no significant difference between the final 
moisture content level of curves of 24 and $60 \mathrm{~min}$ of period. It is also interesting to emphasize that the difference between the average moisture content of intermittent and conventional operations kept getting greater over time.

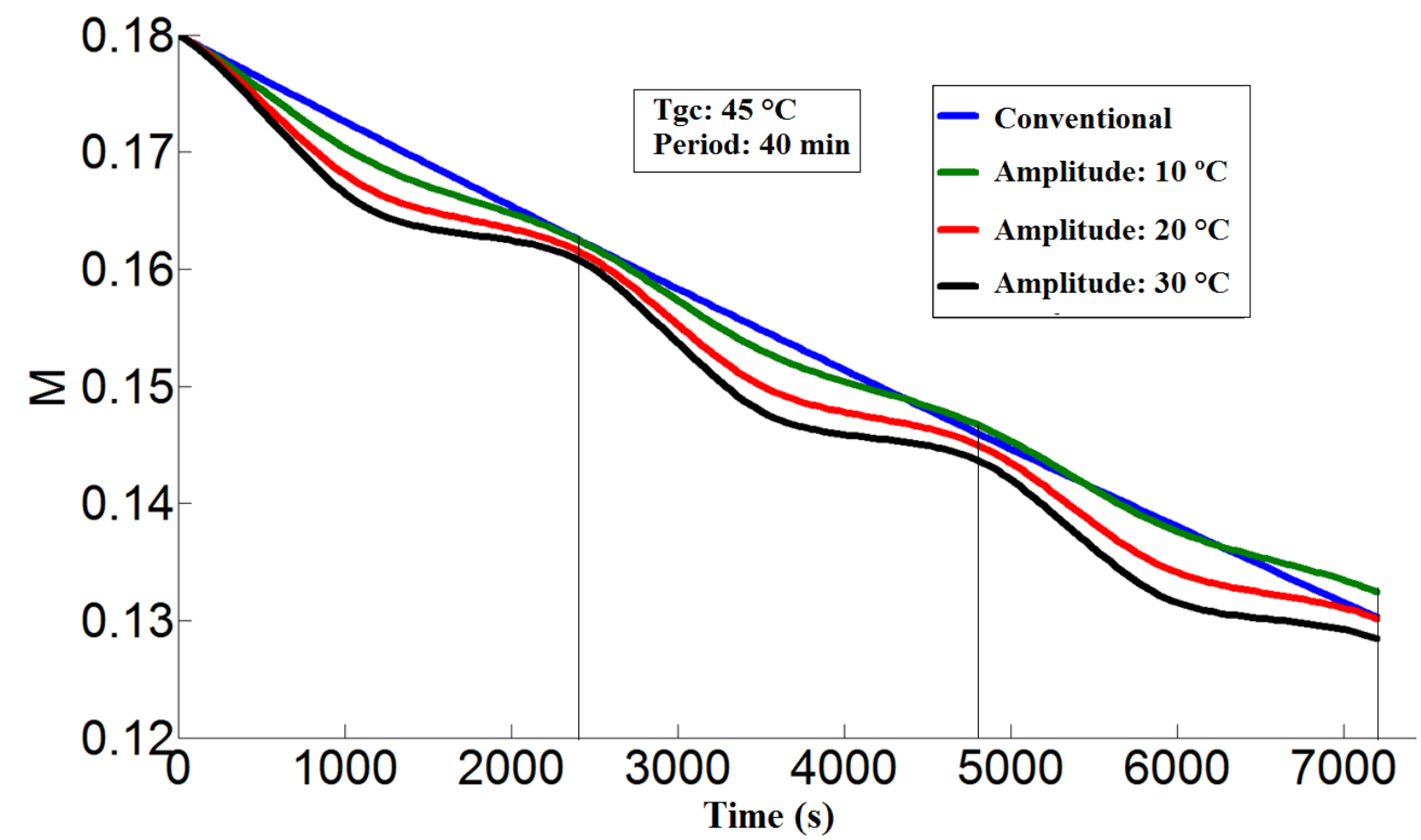

Figure 7. Rice Moisture Content for Different Amplitudes of Temperature Modulation

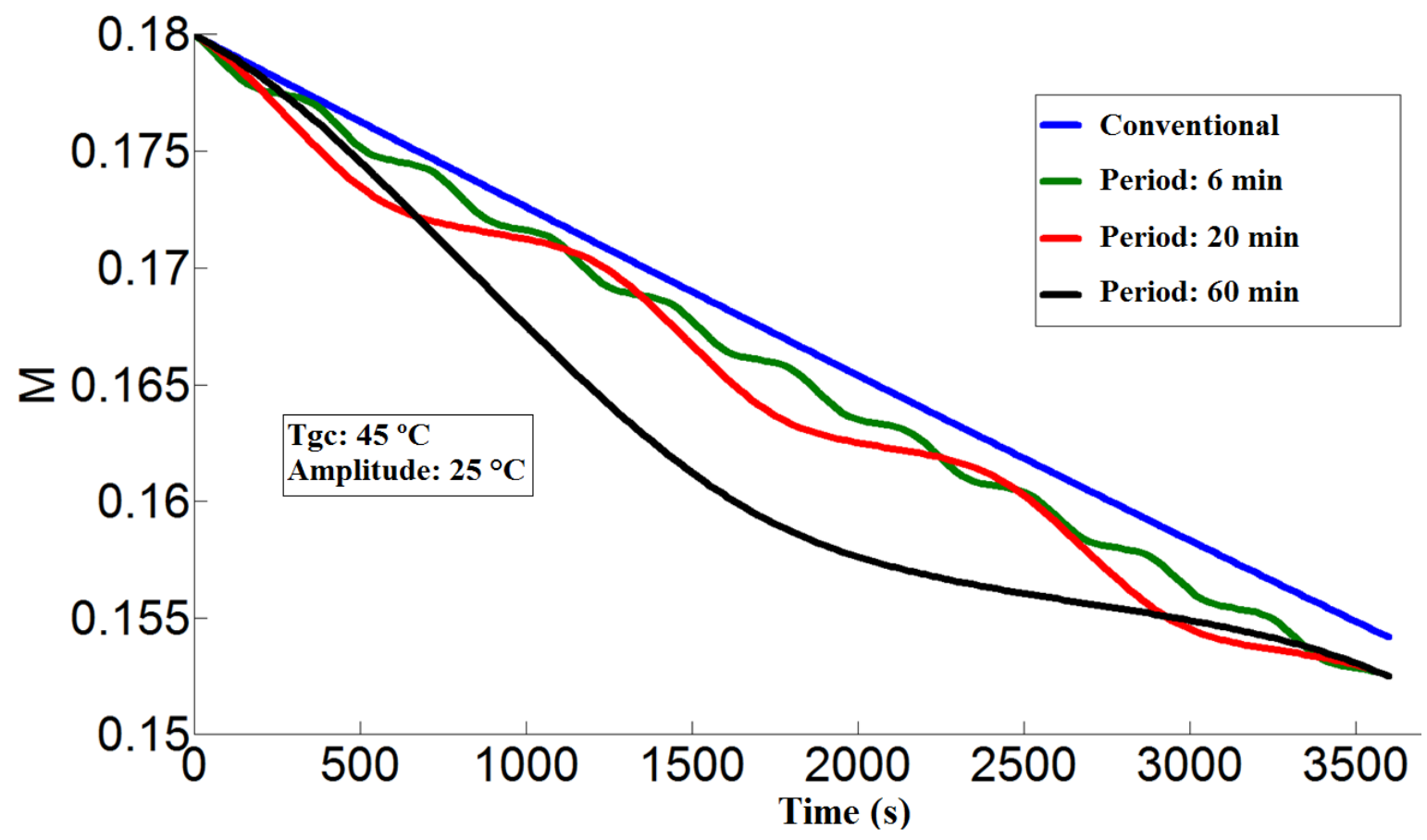

Figure 8. Rice Moisture Content for Different Periods of Temperature Modulation 
ISSN: $1415-7314$

ISSN online: 2317-6717

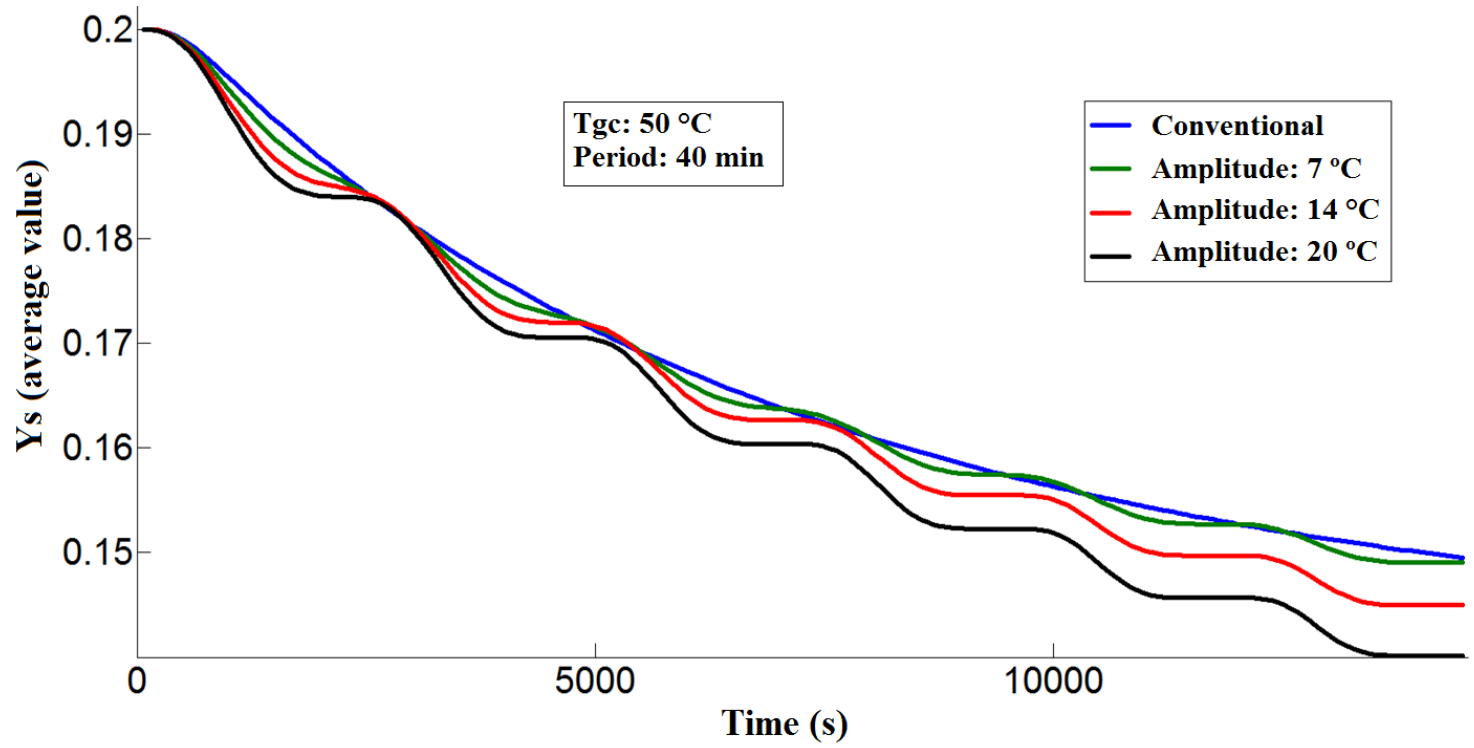

Figure 9. Beans Moisture Content for Different Amplitudes of Temperature Modulation

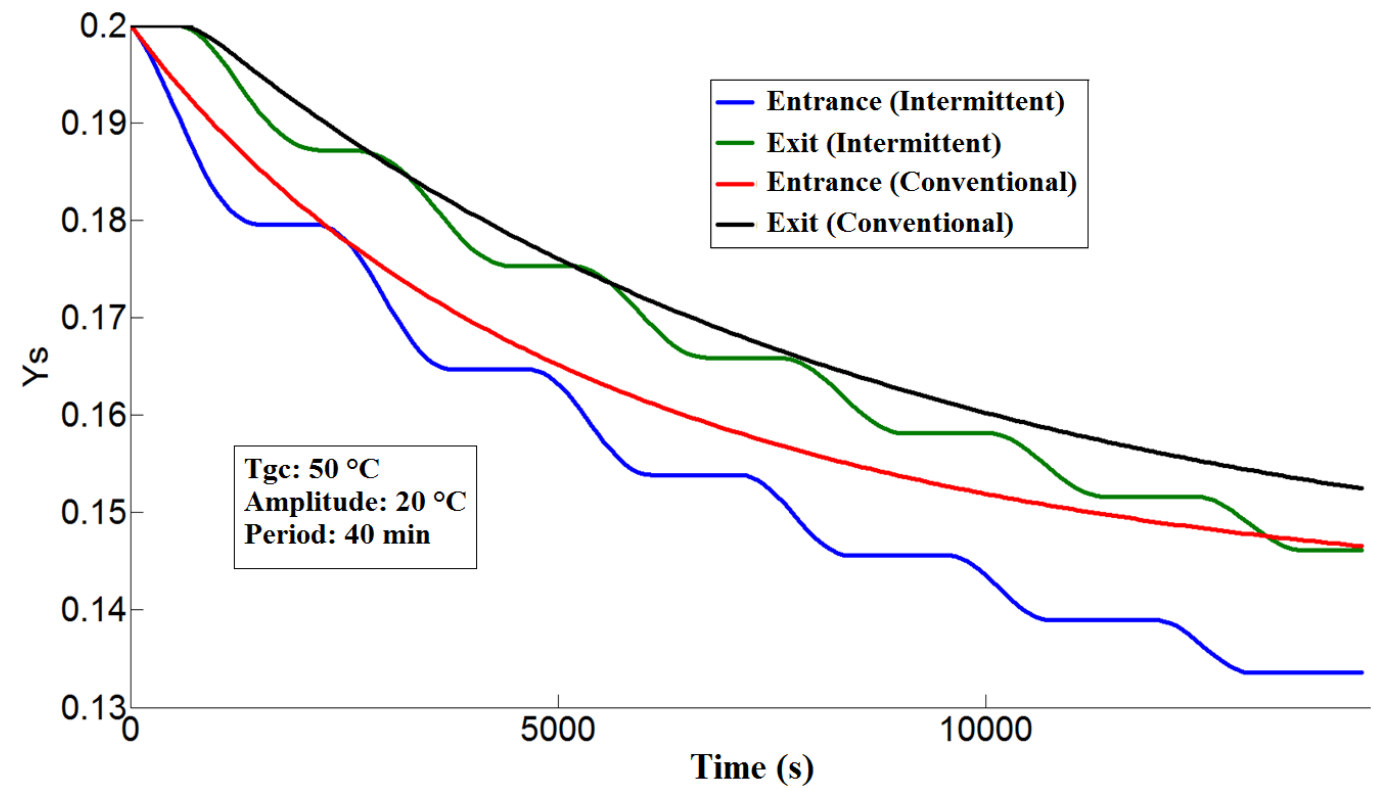

Figure 10. Beans Moisture Content along the Dryer 


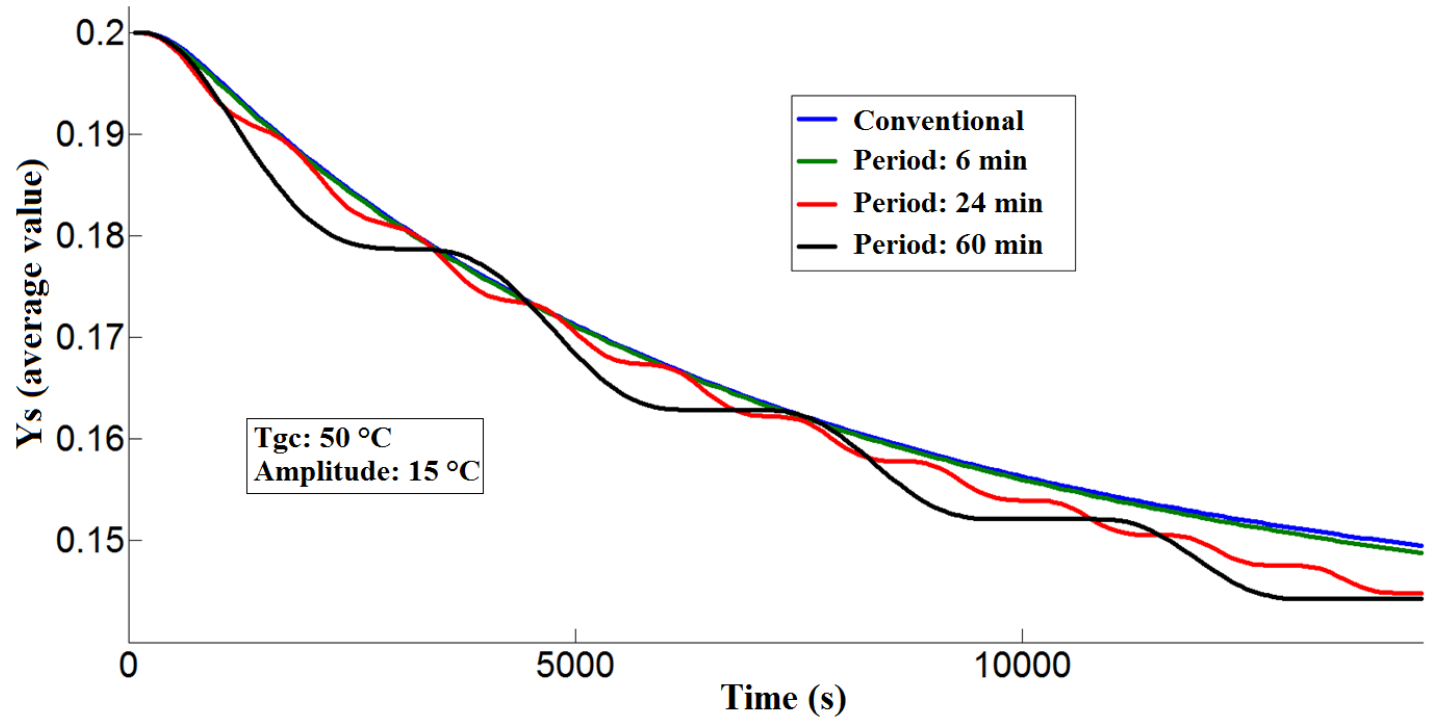

Figure 11. Beans Moisture Content for Different Periods of Temperature Modulation

\section{Conclusion}

Simulations revealed that intermittent operation can increase drying rates by modulating inlet air temperature in comparison with results obtained with conventional operation carried out with the same energy consumption and drying time of intermittent operation. Drying rates also increase by enhancing amplitude related to inlet air temperature modulation for all grain drying models simulated in this work. However, the majority of intermittent operation simulations presented the same final moisture content regardless the value of period related to inlet air temperature modulation. This work indicates that optimization studies related to modulation of inlet air temperature can improve the dryer performance in comparison with results obtained under traditional operation conduct with inlet air in steady-state condition.

\section{Nomenclature}

$\begin{array}{lll}\begin{array}{l}\text { A } \\ \text { Amp }\end{array} & \text { Parameter } & \\ A s & \text { Amplitude } & { }^{\circ} \mathrm{C} \\ B & \text { Surface area } & \left(\mathrm{m}^{2}\right) \\ c p & \text { Parameter } & \\ E & \text { Specific heat } & \mathrm{Jkg}^{-10} \mathrm{C}^{-1} \\ f r & \text { Energy } & \mathrm{J} \\ G & \text { Frequency } & \mathrm{s}^{-1} \\ G g & \text { Mass flow rate } & \mathrm{kgs}^{-1} \\ h a & \text { Gas mass flux } & \mathrm{kgm}^{-2} \mathrm{~s}^{-1} \\ K & \text { Heat transfer coefficient } & \mathrm{Jm}^{-3} \mathrm{~s}^{-1} \mathrm{C}^{-1} \\ K s & \text { Reference mass transfer coefficient } & \mathrm{s}^{-1} \\ \mathrm{kgm}^{-2} \mathrm{~s}^{-1}\end{array}$




$\begin{array}{lll}K_{s} a & \text { Volumetric mass transfer coefficient } & \mathrm{kgm}^{-3} \mathrm{~s}^{-1} \\ M & \text { Moisture content } & \mathrm{kgkg}^{-1} \\ m & \text { Mass } & \mathrm{kg} \\ M R & \text { Moisture content ratio } & \text { dimensionless } \\ P & \text { Pressure } & \mathrm{Pa} \\ T & \text { Temperature } & { }^{\circ} \mathrm{C} \\ t & \text { Time } & \mathrm{s} \\ Y & \text { Moisture content } & \mathrm{kgkg}^{-1} \\ Z & \text { Axial position } & \mathrm{m}\end{array}$

Greek letters

$\begin{array}{lll}\alpha & \text { Parameter } & \\ \beta & \text { Parameter } & \\ \varepsilon & \text { Bed porosity } & \mathrm{m}^{3} \mathrm{~m}^{-3} \\ \lambda & \text { Latent heat of vaporization } & \mathrm{Jkg}^{-1} \\ \rho & \text { Density } & \mathrm{kgm}^{-3}\end{array}$

Subscripts

$\begin{array}{ll}0 & \text { Initial } \\ \text { air } & \text { Air } \\ c & \text { Conventional } \\ e & \text { Equilibrium } \\ g & \text { Gas } \\ I & \text { Intermittent } \\ l & \text { Liquid } \\ s & \text { Solid } \\ s s & \text { Bone-dry } \\ v & \text { Vapor }\end{array}$




\section{References}

AKPINAR, E.K.; BICER, Y.; YILDIZ, C. 2003. Thin layer drying of red pepper. Journal of Food Engineering, 59, 99-104.

ARABHOSSEINI, A.; HUISMAN, W.; VAN BOXTEL, A.; MÜLLER, J. 2009. Modeling of thin layer drying of tarragon (Artemisia dracunculus L.). Industrial Crops and Products, 29, 5359.

BENALI, M. 2012. Drying of yellow pea starch on inert carriers: Drying kinetics, moisture diffusivity, and product quality. Journal of Food Engineering, 110, 337-344.

BON, J.; KUDRA, T. 2007. Enthalpy-Driven Optimization of Intermittent Drying. Drying Technology: An International Journal, 25 (4), 523-532.

BOYCE, D. S. 1965. Grain Moisture and Temperature Changes with Position and Time During Through Drying. J. Agric. Res., v.10, n. 4, p. 333-341.

CALÇADA, L. A. 1994. Modelagem e Simulação de Secadores em Leito Fixo. Dissertação de Mestrado, PEQ, COPPE, UFRJ, Rio de Janeiro - RJ.

CHIN, S.K.; LAW, C.L. 2010. Product Quality and Drying Characteristics of Intermittent Heat Pump Drying of Ganoderma tsugae Murrill. Drying Technology, 28, 1457-1465.

CHINENYE, N. M.; OGUNLOWO, A. S.; OLUKUNLE, O. J. 2010. Cocoa Bean (Theobroma cacao L.) Drying Kinetics. Chilean Journal of Agricultural Research, 70 (4), 633-639.

CHONG, C.H.; LAW, C.L. 2011. Application of Intermittent Drying of Cyclic Temperature and Step-Up Temperature in Enhancing Textural Attributes of Dehydrated Manilkara zapota. Drying Technology: An International Journal, 29 (2), 245-252.

CHUA, K.J.; MUJUMDAR, A.S.; CHOU, S.K. 2003. Intermittent drying of bioproducts - an overview. Bioresource Technology, 90, 285-295.

CIL, B.; TOPUZ, Z. 2010. Fluidized Bed Drying of Corn, Bean and Chickpea. Journal of Food Process Engineering, 33, 1079-1096.

COUTINHO, M. R.; ROMERO, J. A. S.; CONCEIÇÃO, W. A. S., PARAÍSO, P. R.; JORGE, L. M. M. Secagem de Soja em Leito Fixo: Modelo a Duas Fases. XXXIV Congresso Brasileiro de Sistemas Particulados. ENEMP, 2009 Campinas, Brasil.

DEFENDI, R. O; SILVA, R. O.; PARAÍSO, P. R.; JORGE, L. M. M. Secagem Periódica de Soja em Camada Delgada. XX COBEQ Congresso Brasileiro de Engenharia Química, 2014 Florianópolis, Brasil.

DEFENDI, R.O.; NICOLIN, D.J.; PARAÍSO, P.R.; JORGE, L.M.M. 2015a. Assessment of the initial moisture content on soybean drying kinetics and transport properties. Drying Technology: An International Journal, DOI: 10.1080/07373937.2015.1055496

DEFENDI, R.O.; PARAÍSO, P.R.; JORGE, L.M.M. 2015b. The air temperature modulation impact on the drying of soybeans in fixed bed. Drying Technology: An International Journal, DOI: 10.1080/07373937.2015.1060998

DEMIR, V.; GUNHAN, T.; YAGCIOGLU, A. K. 2007. Mathematical modelling of convection drying of green table olives. Biosystems Engineering, 98, 47-53.

FARKAS, I.; RENDIK, Z. 1997. Intermittent thin layer corn drying. Drying Technology: An International Journal, 15 (6-8), 1951-1960.

HENDERSON, S.M.; PERRY, R.L. 1955. Agricultural process engineering, New York, John Wiley \& Sons, Inc.

HERRITSCH, A.; DRONFIELD, J.; NIJDAM, J.J. 2010. Intermittent and Continuous Drying of Red Beech Timber From the Green Condition. Drying Technology, 28, 269-277.

HOLOWATY, S. A.; RAMALLO, L. A.; SCHMALKO, M. E. 2012. Intermittent drying simulation in deep bed dryer of yerba maté. Journal of Food Engineering, 111, 110-114.

JUMAH, R.; AL-KTEIMAT, E.; AL-HAMAD, A.; TELFAH, E. 2007. Constant and Intermittent Drying Characteristics of Olive Cake. Drying Technology, 25, 1417-1422. 
KOWALSKI, S.J.; PAWOWSKI, A. 2010a. Drying of Wet Materials in Intermittent Conditions. Drying Technology: An International Journal, 28 (5), 636-643.

KOWALSKI, S.J.; PAWOWSKI, A. 2010b. Modeling of Kinetics in Stationary and Intermittent Drying. Drying Technology: An International Journal, 28 (8), 1023-1031.

KOWALSKI, S.J.; SZADZINSKA, J. 2014. Convective-intermittent drying of cherries preceded by ultrasonic assisted osmotic dehydration. Chemical Engineering and Processing: Process Intensification, 82, 65-70.

LEWIS, W. K. 1921. The Rate of Drying of Solid Materials. Ind. Eng. Chem., v. 13, p 427-432. LIMA, A.G.B.; NEBRA, S.A. 2001. Theoretical Study of Intermittent Drying (Tempering) in Prolate Spheroidal Bodies. Drying Technology: An International Journal, 19 (8), 1569-1589.

MANCINI, M. C.; MASSARANI, G.; BISCAIA Jr., E. C. 2002a. Transferência de Massa na Secagem de Milho em Secadores de Camada Espessa em Leitos Fixo e Deslizante. Revista Universidade Rural, Série Ciências Exatas e da Terra, Vol. 21 (1 ): 121-129.

MANCINI, M. C.; CALÇADA, L. A.; MASSARANI, G.; BISCAIA Jr., E. C. 2002b. Secagem de Feijão em Leito Fixo. Revista Universidade Rural, Série Ciências Exatas e da Terra, Vol. 21 (1 ): 89-96.

MATA, M. E. R. M. C. 1992. Secagem e Armazenagem de Produtos Agrícolas. Campina Grande, Núcleo de Tecnologia em Armazenagem, Universidade Federal da Paraíba.

MATA, M. E. R. M. C.; DANTAS, L. A.; BRAGA, M. E. D. 1999. Programa Computacional Para Simulação de Secagem de Grãos. Revista Brasileira de Produtos Agroindustriais, Campina Grande, v.1, n.1, p. 33-50.

MEISAMI-ASL, E.; RAFIEE, S.; KEYHANI, A.; TABATABAEEFAR, A. 2010. Determination of suitable thin layer drying curve model for apple slices (variety-Golab). Plant Omics Journal, 3 (3), 103-108.

OLIVEIRA, C.A.; ROCHA, S.C.S. 2007. Intermittent Drying of Beans in a Spouted Bed. Brazilian Journal of Chemical Engineering, 24 (4), 571-585.

ONG, S.P.; LAW, C.L.; HII, C.L. 2012. Optimization of Heat Pump-Assisted Intermittent Drying. Drying Technology, 30, 1676-1687.

PAN, Y.K.; ZHAO, L.J.; HU, W.B. 1998. The effect of tempering-intermittent drying on quality and energy of plant materials. Drying Technology: An International Journal, 17 (9), 1795-1812. PAN, Y.K.; ZHAO, L.J.; DONG, Z.X.; MUJUMDAR, A.S.; KUDRA, T. 1999. Intermittent drying of carrot in a vibrated fluid bed: effect on product quality. Drying Technology: An International Journal, 17 (10), 2323-2340.

PERRY, R. H; GREEN, D. W. 1998. Chemical engineers' handbook. Editora McGraw-Hill, 7 ${ }^{\text {a }}$ Edição. p. 11-1 a 11-28.

RESENDE, O.; CORRÊA, P. C.; GONELI, A. L. D.; RIBEIRO, D. M. 2008. Propriedades Físicas do Feijão Durante a Secagem: Determinação e Modelagem. Ciênc. Agrotec., v. 32 (1), p. 225 230.

SANTOS, C. C.; CANEPPELE, C.; BONFIM-SILVA, E. M. 2012. Massa Específica e Porosidade de Grãos pelo Método de Complementação de Líquidos. Enciclopédia Biosfera, Centro Científico Conhecer, v. 8 (15), p. 1178-1184.

SILVA, J. de S; BERBERT, P. A.; AFONSO, A. D. L.; RUFATO, S. 2000. Qualidade dos Grãos. In: SILVA, J. S. Secagem e Armazenagem de Produtos Agrícolas. Viçosa: Aprenda Fácil. Viçosa, MG. p. $63-104$.

SILVA, V.; FIGUEIREDO, A.R.; COSTA, J.J.; GUINÉ, R.P.F. 2014. Experimental and mathematical study of the discontinuous drying kinetics of pears. Journal of Food Engineering, 134, 30-36.

THOMKAPANICH, O.; SUVARNAKUTA, P.; DEVAHASTIN, S. 2007. Study of Intermittent Low-Pressure Superheated Steam and Vacuum Drying of Heat-Sensitive Material. Drying Technology, 25, 205-223. 
THOMPSON, T. L.; PEART, R. M.; FOSTER, G. H. 1968. Mathematical Simulation of Corn Drying - A New Model. Transactions of the ASAE, 11 (4), 582-586.

VEGA-GÁLVEZ, A.; AH-HEN, K.; CHACANA, M.; VERGARA, J.; MARTÍNEZ-MONZÓ, J.; GARCÍA-SEGOVIA, P.; LEMUS-MONDACA, R.; DI SCALA, K. 2012. Effect of temperature and air velocity on drying kinetics, antioxidant capacity, total phenolic content, colour, texture, and microstructure of apple (var. Granny Smith) slices. Food Chemistry, 132, 5159.

ZHANG, Q.; LITCHFIELD J.B. 1991. An optimization of intermittent corn drying in a laboratory scale thin layer dryer. Drying Technology: An International Journal, 9 (2), 383-395.

\section{Acknowledgements}

This work was supported by the National Council for Scientific and Technological Development - CNPq - Brazil. 